\title{
Studi Komparasi Self-Esteem Pengguna Iphone dan Bukan Pengguna Iphone pada Remaja
}

\author{
Azhar El Hami, Asep Ahmad Sidik \\ Universitas Padjadjaran Jl. Raya Bandung Sumedang KM.21, Kabupaten Sumedang \\ e-mail : azhar.el.hami@unpad.ac.id
}

\begin{abstract}
IPhone as one of the smartphone brand, is often regarded as a prestigious symbol for teenagers. In choosing goods, teenagers also pay attention to the symbolic value that they want to show. These symbols give a certain impact to their self-esteem among teenager. What about the non-iPhone user? The purpose of this study was to see the difference of self-esteem between iPhone users and non-iPhone users. The samples are the students in one of public high school at Garut. The design of this study is quantitative non-experimental with comparative method. The study compared two groups of teenagers: iPhone users $(N=25)$ and non-iPhone users $(N$ =39). All respondents filled out three questionnaires about IPhone Brand Image, Self-Esteem Questionnaire and Self-Esteem iPhone Ownership (SEiO) Questionnaire. The data obtained were tested by t-test on two groups. The results show that there are significant differences of self-esteem between two groups.
\end{abstract}

Keywords: self-esteem, smartphone, iPhone, teenager

\begin{abstract}
Abstrak
IPhone sebagai salah satu brand smartphone, seringkali dianggap sebagai simbol prestisius bagi remaja. Di dalam memilih barang, para remaja juga memperhatikan nilai simbolik yang ingin ditampilkan. Simbol-simbol tersebut memberikan dampak tertentu terhadap self-esteem pada remaja. Lalu bagaimana dengan remaja yang tidak menggunakan/ memiliki iPhone? Penelitian ini bertujuan untuk melihat perbedaan derajat self-esteem pada remaja pengguna/ pemilik iPhone dan remaja bukan pengguna/ pemilik iPhone. Adapun sampel pada penelitian ini adalah siswa di salah satu SMA negeri di kota Garut. Rancangan penelitian ini adalah kuantitatif non-eksperimental dengan metode komparasi. Penelitian ini membandingkan dua kelompok, yaitu kelompok remaja pengguna/ pemilik iPhone $(\mathrm{N}=25)$ dan bukan pengguna/ pemilik iPhone $(\mathrm{N}=39)$. Kepada seluruh responden diberikan kuesioner tentang Citra Merek IPhone, Kuesioner Self-Esteem dan Kuesioner Self-Esteem IPhone Ownership. Data yang diperoleh lalu dilakukan t-test pada dua kelompok. Hasil dari penelitian ini adalah terdapat perbedaan yang signifikan pada self-esteem kedua kelompok remaja tersebut.
\end{abstract}

Kata Kunci: self-esteem, smartphone, iPhone, remaja

\section{Pendahuluan}

Sebagai makhluk sosial, manusia dalam kegiatan sehari-hari tidak lepas dari kegiatan berkomunikasi dengan orang lain. Menurut Davis (1981 dalam Singla, 2008) komunikasi adalah sebagai pemindahan informasi dan pengertian dari satu orang ke orang lain. Dan pada saat ini salah satu kebutuhan manusia sebagai konsumen adalah alat komunikasi yang digunakan untuk berhubungan dengan keluarga, teman, dan orang-orang yang mereka kenal.
Telepon genggam merupakan salah satu perangkat komunikasi yang paling sering digunakan dalam kegiatan seharihari (Yildirim, 2014). Telepon genggam telah membuat perubahan dari alat komunikasi sederhana menjadi nirkabel canggih perangkat mobile yang sering disebut sebagai 'smartphone' (Cheever, Rosen, Carrier dan Chavez, 2014). Smartphone adalah telepon selular yaitu perangkat yang terdiri dari mikroprosesor, memori dan layar serta modem yang menyatu dalam perangkat 
tersebut (Williams \& Sawyer, 2011). Secara umum, smartphone adalah ponsel multifungsi yang menggabungkan beberapa fungsi dari sebuah PDA (personal digital assistance), seperti personal scheduler, kalender, phone book, dan fitur lainnya seperti koneksi internet, Wi-Fi, GPS, dan lain-lain. Saat ini terdapat dua jenis Operation System (OS) dalam smartphone yang dikenal oleh masyarakat, yaitu Android yang dibawa oleh beberapa brand smartphone seperti, Samsung, Sony, Cross dan lain-lainnya. Serta ada iOS yang dalam hal ini hanya diterapkan oleh brand dari Apple.

Indonesia menjadi salah satu negara dengan perkembangan smartphone yang cukup pesat. Mengutip data yang dimiliki oleh eMarketer (2015), pada akhir tahun 2015 diperkirakan sekitar 55 juta pengguna smartphone di Indonesia. Berdasarkan laporan dari Smartphone User Personal Report (SUPR) yang dirilis oleh perusahaan produsen mobile platform ternama dunia, yaitu Vserv pada tahun 2015, memaparkan data bahwa pengguna smartphone di Indonesia $61 \%$ adalah dari kalangan remaja.

Berdasarkan survey yang dilakukan oleh SecurEnvovy yaitu sebuah perusahaan berbasis teknologi di Inggris tahun 2012 dinyatakan bahwa rentang usia 18-24 tahun merupakan rentang usia yang sangat tergantung dengan smartphone (www. seccurenvovy.com). Remaja (adolescence) merupakan golongan yang berada pada episode perkembangan yang bermula pada usia belasan tahun, dari umur 13 tahun sampai 19 tahun (Hurlock, 1990). Masa ini merupakan masa pembentukan identitas diri, masa perkembangan dalam menjalin hubungan dengan teman sebaya, dan juga masa pemilihan orang-orang yang akan diterima dalam kehidupannya.

Penampilan fisik merupakan prioritas utama yang menjadi perhatian para remaja, bahkan banyak yang hanya mau membeli produk dengan merek tertentu, hanya untuk meningkatkan harga diri dan menambah kepercayaan dirinya. Sejumlah penelitian telah menemukan bahwa penampilan fisik merupakan kontributor yang sangat berpengaruh pada rasa percaya diri remaja (Santrock, 2002). Salah satu bentuk perilaku remaja dalam menambah penampilan fisiknya di mata kelompoknya adalah dengan mengikuti mode yang diminati oleh kelompok sebayanya (Mappiare, 1982).

Engel (1994) menjelaskan faktorfaktor yang memengaruhi perilaku membeli pada remaja salah satunya adalah adanya faktor internal, dimana faktor internal ini meliputi (1) motivasi dan self-esteem (harga diri), (2) pengamatan dan proses belajar, (3) kepribadian dan konsep diri. Dengan membeli, menunjukkan, dan menggunakan barang-barang tertentu mereka mencoba menunjukkan nilai simbolik mereka pada individu dan orangorang di sekitarnya (Grubb dan Grathwohl, 1967 dalam Sirgy, 1982). Simbol status ini seringkali dianggap dapat mengangkat wibawa, kehormatan, dan juga memperbesar kemungkinan untuk memperoleh dukungan sosial dari orangorang di sekitarnya, maka hal ini berdampak terhadap seberapa positif self-esteem seorang individu tersebut. Tingkah laku membeli merupakan fungsi dari pencitraan individu yang menunjukkan individu seperti apa dirinya dan bagaimana orang lain melihatnya sehingga individu tersebut mudah dalam membina hubungan dengan orang lain.

Menurut Branden (1994), self-esteem adalah penjumlahan terintegrasi dari self-efficacy dan self-respect. Self-esteem merupakan disposisi individu untuk mengalami dirinya sebagai orang yang kompeten dalam menghadapi tantangantantangan dasar kehidupan dan merasa layak untuk bahagia. Sehingga dapat dikatakan bahwa perkembangan self-esteem remaja akan positif atau baik dengan cara mengkonsumsi atau memakai produk yang memiliki citra produk yang baik sesuai dengan citra dirinya. 
IPhone adalah merek smartphone yang cukup populer di kalangan remaja, baik di kota besar maupun bukan kota besar. Survey awal yang dilakukan di salah satu SMA di kota Garut, didapatkan bahwa $67 \%$ responden mengatakan memilih produk iPhone sebagai produk smartphone yang mereka inginkan. Wawancara awal pun dilakukan untuk melihat bagaimana pandangan mereka tentang produk iPhone tersebut. Para responden mengatakan bahwa iPhone merupakan produk yang dipersepsikan sebagai barang mewah, hanya kalangan dengan sosial-ekonomi menengah-atas yang menggunakannya, dan terlihat keren. Hal ini secara tidak langsung membuat para penggunanya merasa menjadi lebih modis, berkelas dan mengesankan sebagai individu yang high-tech.

Selain itu, wawancara awal pun dilakukan terhadap 15 responden yang menggunakan iPhone untuk melihat karakteristik pribadi, pandangan mereka tentang produk tersebut dan alasan mereka memilih iPhone sebagai produk smartphone yang mereka pilih. Dari proses wawancara tersebut didapat hasil bahwa 12 dari 15 responden adalah orang yang senang bergaul dan berinteraksi dengan teman sebayanya, memiliki banyak teman, termasuk dalam kelompok populer di sekolah dan mereka merasa sangat senang dengan keadaan mereka saat ini. Disamping itu, sebanyak 8 responden mengatakan alasan mereka menggunakan iPhone karena banyak dipakai oleh teman dan keluarga, trendy, modern dan terkesan mewah. Mereka menyukai fitur yang dimiliki dan kecanggihan yang ditawarkan, mengaku merasa menjadi remaja yang high-tech. Selain itu dengan menggunakan brand yang bergengsi ini mereka merasa percaya diri pada saat melakukan berbagai kegiatan.

Berdasarkan data awal tersebut peneliti ingin mengetahui apakah terdapat perbedaan self-esteem pada remaja pengguna produk iPhone dan non-iPhone.

\section{Self-Esteem}

Kata esteem berasal dari bahasa Latin aestimare, yang berarti "to estimate or to appraise" (menilai). Berikut adalah definisi self-esteem dari beberapa tokoh; (1) Selfesteem adalah suatu sikap positif atau negatif terhadap objek khusus, yaitu self (Rosenberg dalam Burns, 1993); (2) Selfesteem secara singkat dapat didefinisikan sebagai komponen evaluative terhadap diri sendiri, yang melibatkan affect (perasaan), attitude (sikap), serta appraisal (penilaian) atau judgment (Rosenberg dalam Blascovich dan Tomaka, 1991). (3) Selfesteem merupakan gambaran seberapa positif atau negatif individu menilai dirinya (Steinberg, 2002). (4) Self-esteem merupakan penilaian dan penghargaan diri yang dilakukan individu terhadap dirinya sendiri (Coopersmith dalam Brehm dan Kassin, 1996)

Menurut Branden (1994), definisi selfesteem: "it is an intergrated sum of selfconfidence and self-respect. It is the disposition to experience one self as competent to cope with the basic challenges of life and as worthy of happiness" yang berarti self-esteem adalah penjumlahan terintegrasi dari self-confidence dan selfrespect. Self-esteem merupakan disposisi individu untuk mengalami dirinya sebagai orang yang kompeten dalam menghadapi tantangan-tantangan dasar kehidupan dan merasa layak untuk bahagia. Dari definisi Branden (1994) ini dapat digambarkan bagaimana self-esteem yang baik dapat bermanfaat bagi pengembangan diri seseorang. Self-esteem akan menciptakan suatu harapan sehingga individu mampu memprediksi hal yang tepat baginya. Prediksi ini lebih kuat daripada pengalaman masa lalu, yang akan mempengaruhi pikiran dan motivasi dalam memutuskan tindakan yang tepat. Tindakan ini akan mengkonfirmasi dan memperkuat sistem belief individu (Kelley, 1979).

Para ahli Sosiologi dan Psikologi Sosial memandang bahwa self-esteem adalah bagian dari sosial self yang dibentuk 
dari hasil internalisasi individu mengenai dirinya yang diperoleh berdasarkan informasi dari lingkungan (Taylor, Peplau, dan Sears, 2000). Oleh karena itu, dalam penjelasan mengenai self-esteem, akan terkait pula dengan pembahasan mengenai self-concept, dimana self-concept merupakan salah satu dari tiga aspek sosial self yang saling berhubungan (interrelated). Aspek kedua yaitu self-esteem, yang merupakan komponen afektif dari self, yang ketiga self-presentation, yang merupakan manifestasi tingkah laku dari self. Jika self-concept merupakan deskripsi dari apa yang seseorang persepsikan terhadap dirinya sendiri, maka self-esteem merupakan evaluasi seseorang terhadap semua yang ia persepsikan sebagai dirinya (Gray, 1997).

\section{Komponen-Komponen Self-Esteem}

Self-esteem memiliki dua komponen yang saling berhubungan erat, artinya salah satu komponen harus dilengkapi dengan komponen yang lain agar dapat membentuk self esteem. Kedua komponen tersebut, yaitu; (1) Self-efficacy, yaitu keyakinan individu untuk menjalankan proses mentalnya, yaitu rasa yakin akan kemampuan menjalani proses mental, rasa yakin akan kemampuan dalam berpikir, dalam proses menilai, memilih, dan memutuskan; yakin dengan kemampuannya memahami realita dan fakta yang berkaitan dengan kebutuhan dan minatnya; cognitive self-reliance. Selfefficacy ini berarti individu yakin akan kemampuannya untuk mempelajari apa yang dibutuhkan dan mengerjakan apa yang dibutuhkan untuk mencapai tujuan individu tersebut. Self-efficacy pun merupakan pengakuan individu dapat berpikir, menilai, mengetahui, dan memperbaiki kesalahan. Dengan kata lain individu tersebut percaya pada proses mental dan kemampuannya. Branden (1994) menyebutkan bahwa apabila seseorang mengalami defisiensi dalam selfefficacy sangatlah berbahaya, karena individu ini akan terikat pada yang ia ketahui dan akan mengalami kesulitan dalam beradaptasi pada tuntutan atau situasi yang baru. (2) Self-respect, yaitu keyakinan akan nilai-nilai diri; sikap positif yang mengarah pada rasa layak untuk hidup dan merasa bahagia; merasa nyaman dalam mengeluarkan pikiran-pikiran, keinginankeinginan, dan kebutuhan dengan baik; merasa bahwa kebahagiaan merupakan hak asasi bagi dirinya. Individu yang memiliki self-respect akan merasakan bahwa hidupnya bermakna, memiliki keyakinan bahwa kehidupan dan keberadaannya dapat membantu orang lain, merasa bahwa dirinya adalah individu yang baik, berguna, layak dihormati, dan layak memperjuangkan hak yang dimiliki untuk mencapai kesuksesan dan pemenuhan dirinya.

\section{Faktor-Faktor yang Memengaruhi Self- Esteem}

Faktor lingkungan. Meskipun sumber utama pembentukan self-esteem bersifat internal, artinya tergantung pada tindakan individu sendiri, bukan pada apa yang orang lain lakukan, kenyataannya, pembentukan self-esteem juga tidak terlepas dari faktor eksternal, yaitu lingkungan. Menurut Egan (1976 dalam Kelley, 1979), individu mempersepsikan dirinya melalui feedback dari orang lain dan dari hasil observasi terhadap konsekuensi yang didapat dari tindakannya. Sejalan dengan proses kedewasaan, keluarga, teman, dan masyarakat pada umunya juga menanamkan nilai dan norma yang berlaku agar individu akan dinilai berdasarkan norma-norma tersebut.

Menurut Fuhrmann (1990), individu belajar mengevaluasi diri sesuai dengan hasil totalitas interaksi dan pengalaman yang terjadi pada dirinya. Penerimaan lingkungan terhadap individu akan berpengaruh terhadap pembentukan self-esteem. Proses mempersepsi pengalaman terjadi bersamaan dengan proses pemaknaan dan penilaian terhadap 
lingkungan. Secara tidak sadar, pengalaman pribadi yang telah dipersepsikan individu di masa lalu akan memengaruhinya untuk menilai, memandang, dan menetapkan keberadaan dirinya. Pengalaman yang dipersepsikan sebagai pengalaman positif atau menyenangkan akan membuat individu cenderung memandang dirinya kompeten dalam menghadapi tantangan hidup, yang selanjutnya akan membentuk self-efficacy pada individu. Self-respect terbentuk bila individu diperlakukan penuh respek oleh orang lain di lingkungannya, memiliki pengalaman berinteraksi secara tinggi dan memuaskan dengan orang lain, sehingga ia merasa yakin bahwa dirinya berguna dan bermakna bagi orang lain.

Faktor Emosi. Terdapat hubungan dua arah antara self-esteem dengan cara berfikir serta penghayatan emosi. Self-esteem disebut juga generator yang memengaruhi cara individu berpikir dan menghayati emosi. Self-esteem yang tinggi akan lebih banyak menghasilkan emosi positif, seperti rasa nyaman dan bahagia akan apa yang ada pada dirinya. Emosi positif akan memudahkan individu meyakini kemampuan dan keberhargaan dirinya, yang akan memperkuat kembali self-esteem-nya. Self-esteem yang rendah akan lebih banyak menghasilkan emosi negatif, seperti marah, kecewa, takut, dan putus asa, yang nantinya akan meningkatkan keraguan akan dirinya dan melemahkan self-esteem (Branden, 1994).

Self-esteem yang tinggi akan meningkatkan afek positif dengan memberi pertahanan pada seseorang melawan stress dan emosi-emosi negatif lainnya serta dengan meningkatkan penyesuaian dirinya, sedangkan self-esteem yang rendah berhubungan erat dengan depresi, kecemasan, dan maladjustment. Sebuah penelitian menemukan hasil bahwa orang dengan self-esteem yang rendah sering mengalami emosi-emosi negatif dari orang dengan self-esteem yang tinggi (Cutrona, 1982; Goswick dan Jones, 1981; Leary,
1983; Taylor dan Brown, 1988; White, 1981 dalam Hogg dan Vaughan, 2002).

Berdasarkan penjelasan di atas, individu akan melakukan evaluasi terhadap dirinya sesuai dengan totalitas interaksi dan pengalaman yang terjadi pada dirinya, dimana penerimaan lingkungan terhadap individu akan berpengaruh terhadap pembentukan self-esteem, terutama pada remaja. Self-esteem tinggi terbentuk karena pengalaman-pengalaman yang dimiliki dan penerimaan lingkungan terhadap dirinya sangat positif. Demikian pula sebaliknya. Hal ini bisa diartikan bahwa individu akan mengupayakan mencari simbol yang dapat memberikan pengalaman positif dan penerimaan lingkungan yang baik, dalam hal ini memiliki atau menggunakan iPhone, untuk meningkatkan self-esteem yang dimilikinya. Berdasarkan asumsi tersebut maka penelitian ini ingin membuktikan bahwa para remaja pengguna atau pemilik iPhone memiliki self-esteem yang tidak lebih tinggi dibandingkan dengan remaja yang tidak menggunakan atau memiliki iPhone.

\section{Metode Penelitian}

Rancangan penelitian dalam penelitian ini adalah rancangan non-eksperimental kuantitatif dengan metode penelitian komparasi. Partisipan pada penelitian ini seluruhnya berjumlah 84 siswa-siswi di salah satu SMA di kota Garut yang dibagi ke dalam dua kelompok. Kelompok pertama adalah kelompok remaja yang menggunakan iPhone sebanyak 35 siswa dan kelompok kedua adalah kelompok remaja bukan pengguna iPhone sebanyak 49 siswa. Teknik sampling yang digunakan dalam penelitian adalah accidental sampling, yaitu memilih partisipan yang tersedia (Leary, 2012).

Kepada kedua kelompok responden diberikan dua kuesioner awal, yaitu (1) Kuesioner Citra Produk (reliabilitas alat ukur 0.815). Alat ukur ini terdiri dari 26 item yang peneliti kembangkan melalui konsep brand image - Staton (1987). (2) 
Tabel 1

Gambaran Citra Produk iPhone

\begin{tabular}{ccccccc}
\hline \multirow{2}{*}{ Kategori } & & \multicolumn{2}{c}{ Kelompok } \\
& & \multicolumn{2}{c}{ Non IPhone } & \multicolumn{2}{c}{ Iphone } \\
& & $\mathrm{f}$ & $\%$ & $\mathrm{f}$ & $\%$ \\
\hline \multirow{2}{*}{ Citra Produk } & Negatif & 1 & $2,04 \%$ & 0 & $0 \%$ \\
& Positif & 48 & $97,96 \%$ & 35 & $100 \%$ \\
& & Total & 49 & $100 \%$ & 35 & $100 \%$ \\
\hline
\end{tabular}

Tabel 2

Gambaran Self-Esteem Responden

\begin{tabular}{cccccc}
\hline & \multicolumn{5}{c}{ Kelompok } \\
\cline { 2 - 5 } Self Esteem & \multirow{2}{*}{ Kategori } & Non Iphone & Iphone \\
\cline { 2 - 5 } & Rendah & 9 & $18,75 \%$ & 10 & $28,75 \%$ \\
\cline { 2 - 5 } & Tinggi & 39 & $81,25 \%$ & 25 & $71,43 \%$ \\
\hline
\end{tabular}

Tabel 3

Tabel Data Kuesioner SEO Kelompok

\begin{tabular}{lcccccccccc}
\hline \multirow{2}{*}{ Kelompok } & $\mathrm{N}$ & \multicolumn{4}{c}{ Mean } & \multicolumn{4}{c}{ Standar Deviation } & \multicolumn{3}{c}{ Standar Error Mean } \\
\cline { 2 - 10 } & & $\begin{array}{c}\text { Self } \\
\text { Esteem }\end{array}$ & $\begin{array}{c}\text { Self } \\
\text { Efficacy }\end{array}$ & $\begin{array}{c}\text { Self } \\
\text { Respect }\end{array}$ & $\begin{array}{c}\text { Self } \\
\text { Esteem }\end{array}$ & $\begin{array}{c}\text { Self } \\
\text { Efficacy }\end{array}$ & $\begin{array}{c}\text { Self } \\
\text { Respect }\end{array}$ & $\begin{array}{c}\text { Self } \\
\text { Esteem }\end{array}$ & $\begin{array}{c}\text { Self } \\
\text { Efficacy }\end{array}$ & $\begin{array}{c}\text { Self } \\
\text { Respect }\end{array}$ \\
\hline $\begin{array}{l}\text { Bukan Pengguna } \\
\text { pemilik iPhone }\end{array}$ & 39 & 53,77 & 26,72 & 27,05 & 5,08 & 2,89 & 2,98 & 0,81 & 0,46 & 0,48 \\
$\begin{array}{l}\text { Pengguna } \\
\text { Pemilik iPhone }\end{array}$ & 25 & 44,36 & 23,52 & 20,84 & 5,59 & 4,00 & 2,32 & 1,12 & 0,80 & 0,46 \\
\hline
\end{tabular}

Kuesioner tentang self-esteem (reliabilitas alat ukur 0.784). Adapun konsep yang digunakan untuk mengukur self-esteem ini adalah konsep yang dikembangkan oleh Branden (1994). Hal ini dilakukan untuk melihat gambaran self-esteem responden sebagai pribadi.

Kedua kuesioner tersebut digunakan untuk menjaga homogenitas responden yaitu responden yang memiliki persepsi yang sama terkait dengan citra produk iPhone dan juga memiliki derajat selfesteem yang tidak berbeda diantara kedua kelompok. Responden dengan persepsi positif terhadap citra produk iPhone dan responden yang memiliki self-esteem yang positif akan menjadi responden yang akan mengisi kuesioner ke-3, yaitu pengukuran tentang derajat self-esteem ketika dikaitkan dengan konteks pengguna/ pemilik iPhone dengan menggunakan kuesioner SelfEsteem iPhone Ownership (SEiO). Kuesioner ini dikembangkan oleh peneliti berdasarkan teori Rosenberg, Schooler dan Schoenbach (1989), mengenai self-esteem dimana terdapat dua aspek, yaitu selfefficacy dan self-respect dikaitkan dengan kepemilikan iPhone. SEiO ini mengukur sejauhmana rasa keberhargaan diri individu ketika ia memiliki/ tidak memiliki gadget dengan merek iPhone. Penggunaan teori yang berbeda dalam self-esteem ini untuk menghindari adanya efek belajar pada seluruh responden. Adapun reliabilitas alat ukur SEiO ini adalah 0.709. Skor total dari SEiO inilah yang akan digunakan sebagai 
pembeda derajat self-esteem pada kelompok remaja pengguna/ pemilik iPhone dengan kelompok remaja bukan pengguna/ pemilik iPhone. Adapun teknik analisis statistik yang digunakan adalah dengan menggunakan uji-t untuk melihat perbedaan antara kedua kelompok.

\section{Hasil Penelitian dan Pembahasan}

\section{Citra Produk}

Berdasarkan hasil pengukuran pertama terkait dengan citra produk iPhone, maka didapatkan hasil seperti yang terlihat pada tabel 1. Berdasarkan tabel tersebut didapatkan hasil bahwa pada kelompok pengguna/ pemilik iPhone seluruhnya mempersepsi positif terhadap citra produk iPhone. Sementara pada kelompok bukan pengguna/ pemilik iPhone didapatkan hasil bahwa 48 responden memiliki persepsi positif terhadap citra produk iPhone, sementara 1 responden memiliki citra negatif, sehingga 1 responden ini tidak diikutkan dalam pengukuran yang kedua mengenai self-esteem.

\section{Self-Esteem}

Berdasarkan hasil pengukuran terkait dengan self-esteem dari responden, maka didapatkan hasil yang tertera pada tabel 2 . Dari tabel tersebut diperoleh hasil bahwa 39 dari 48 responden pada kelompok bukan pengguna/ pemilik iPhone memiliki derajat self-esteem yang tinggi dan 9 responden lainnya memiliki derajat self-esteem yang rendah. Sementara pada kelompok pengguna/ pemilik iPhone sebanyak 25 dari 35 responden berada pada kategori selfesteem tinggi dan 10 sisanya berada pada kategori rendah.

Berdasarkan hasil tersebut, maka jumlah responden untuk tahap akhir dalam melihat perbedaan self-esteem ketika dikaitkan dengan penggunaan/ kepemilikan iPhone adalah 39 untuk kelompok bukan pengguna/ pemilik iPhone dan 25 responden untuk kelompok penguna/ pemilik iPhone.

Setelah dilakukan pengukuran terakhir dengan menggunakan alat ukur SEiO, dan diuji secara statistik dengan menggunakan uji t, maka didapatkan hasil bahwa terdapat perbedaan yang signifikan antara kelompok bukan pengguna/ pemilik iPhone dengan kelompok pengguna/ pemilik iPhone ( $\mathrm{p}$ value < 0.05). Kelompok bukan pengguna/ pemilik iPhone memiliki nilai rata-rata yang lebih besar dibandingkan dengan kelompok pengguna/ pemilik iPhone, seperti yang tertera pada tabel 3 .

Demikian pula ketika melihat kedua dimensi self-esteem, yaitu self-efficacy dan self-respect didapatkan bahwa $p$-value lebih kecil dari 0,05 sehingga dinyatakan terdapat perbedaan yang signifikan untuk self-efficacy dan self-respect pada kelompok bukan pengguna/ pemilik iPhone dengan kelompok pengguna/ pemilik iPhone. Nilai rerata baik untuk self-efficacy maupun self-respect pada kelompok bukan pengguna/ pemilik iPhone lebih tinggi dibandingkan dengan kelompok pengguna/ pemilik iPhone.

Hal ini menunjukkan bahwa iPhone memiliki pengaruh yang signifikan guna meningkatkan derajat self-esteem pada remaja. Grubb dan Grathohl (1967) mengatakan bahwa dengan membeli, menunjukkan, dan menggunakan barangbarang tertentu para remaja mencoba menunjukkan nilai simbolik mereka pada individu dan orang-orang di sekitarnya. Simbol status ini seringkali dianggap dapat mengangkat wibawa, kehormatan, dan juga memperbesar kemungkinan untuk memperoleh dukungan sosial dari orangorang di sekitarnya, dan berdampak positif terhadap self-esteem individu. Berdasarkan hal tersebut tampaknya ketika remaja menggunakan iPhone maka mereka ingin menampilkan simbol-simbol status yang dapat membuat mereka diakui oleh lingkungan, mendapatkan perhatian ataupun kemungkinan untuk mendapatkan dukungan sosial. Hal ini secara tidak 
langsung dapat mengangkat derajat self-esteem dari remaja tersebut. Sementara sebaliknya, ketika remaja yang tidak menggunakan iPhone menganggap bahwa hal tersebut bukan merupakan bagian yang penting dalam kehidupannya, dan tidak berdampak pada peningkatan derajat self-esteem yang ada pada diri mereka.

Sementara itu, salah satu implikasi dari meningkatnya self-esteem (Branden, 1994) adalah semakin mudah seseorang dalam membina hubungan yang terpelihara dengan orang lain. Hal ini cukup memberikan gambaran yang dapat dipahami mengenai perilaku para remaja pengguna iPhone yang berdasarkan data awal didapatkan hasil bahwa mereka adalah pribadi-pribadi yang cukup senang bergaul, cukup populer di antara teman-temannya dan cukup disukai oleh teman-temannya. Dengan kata lain, dengan menggunakan iPhone mereka merasa lebih yakin untuk dapat menjalin relasi dengan orang lain.

\section{Simpulan dan Saran}

Berdasarkan hasil penelitian, maka dapat disimpulkan bahwa terdapat perbedaan self-esteem yang signifikan ketika dikaitkan dengan kepemilikan iPhone pada kelompok pengguna/ pemilik iPhone dengan kelompok yang bukan pengguna/ pemilik iPhone. Pada kelompok pengguna/ pemilik iPhone derajat self-esteem yang dimiliki lebih rendah dibandingkan dengan kelompok bukan pengguna/ pemilik iPhone.

Demikian pula dengan derajat self-respect yang merupakan aspek dari self-esteem. Pada kelompok remaja pengguna/ pemilik iPhone menunjukkan tingkat yang lebih rendah secara signifikan dibandingkan dengan remaja dari kelompok bukan pengguna/ pemilik iPhone. Sementara pada aspek self-efficacy juga menunjukkan hal yang sama. Kondisi ini menunjukkan bahwa ternyata iPhone merupakan simbol yang dapat meningkatkan derajat self-esteem remaja pada kelompok tersebut. Dengan mengunakan iPhone maka ada rasa keberhargaan diri yang meningkat pada dirinya.

Implikasi dari penelitian ini dalam keilmuan adalah memberikan bukti awal di bidang Psikologi Konsumen bahwa kepemilikan terhadap suatu barang yang dianggap prestisius berdampak pada peningkatan self-esteem terutama pada remaja. Penelitian lebih lanjut memang diperlukan terkait dengan jumah sampel yang lebih representatif guna generalisasi dari penemuan ini. Disamping itu variasi sekolah antara kota besar dan kota kecil bisa juga dilakukan untuk bisa menggambarkan lebih komprehensif mengenai gambaran self-esteem ini pada remaja jika dikaitkan dengan kepemilikan barang yang dianggap prestisius.

Sementara secara praktis, hasil dari penelitian ini bisa dimanfaatkan bagi para produsen ataupun pemasar untuk menjadi masukan mengenai pentingnya membentuk suatu citra produk yang prestisius dalam menciptakan suatu produk terutama produk-produk yang ditujukan bagi kalangan remaja.

\section{Daftar Pustaka}

Blascovich, J. \& Tomaka, J. (1991). Measures of self-esteem. In: Robinson, J.P., Shaver, P.R., Wrightsman, L.S., editors. Measures of Personality and Social Psychological Attitudes, Academic Press: London.

Branden, N. (1994). The Six Pillars of SelfEsteem, United States of America: Bantam Books.

Brehm, S.S. \& Kassin, S.M. (1993). Social Psychology, Boston: Houghton Mifflin Company.

Burns, R.B. (1993). Konsep Diri (Teori, Pengukuran, Perkembangan dan. Prilaku), Jakarta: Penerbit Arca.

Cheever, N.A., Rosen, L.D., Carrier, L.M., \& Chavez, A. (2014). Out of Sight is not Out of Mind: The Impact of Restricting Wireless Mobile Device 
Use on Anxiety Levels among Low, Moderate and High Users, Computers in Human Behavior (Forgays, Hyman, \& Schreiber, 2014), 37. pp. 290-297.

Engel, J.F., Roger, D.B., \& Paul, W.M. (1994). Perilaku Konsumen jilid I, Jakarta: Binarupa Aksara.

Fuhrmann, B.S. (1990). Adolesences, England: A Division of Scott Foresman and Company.

Gray, A. (1997). Indigenous Rights and Development: Self-Determination in an Amazonian Community, Oxford: Berghahn Books.

Grubb. E.L. \& Grathwhohl, H.L. (1967). Consumer Self-Concept, Symbolism, and Market Behaviour: A Theoretical Approach, Journal of Marketing, 31, 22-27.

Hogg, M.A. \& Vaughan, G.M. (2002). Social Psychology (3rd ed), London: Prentice-Hall.

Hurlock, E.B. (1990). Psikologi Perkembangan Edisi 5, Jakarta: Erlangga.

Kelley, H.H. (1979). Attribution Theory in Social Psychology, Lincoln: University of. Nebraska Press.

Leary, M.R. (2012). Introduction to Behavioral Research Methods 6th ed, Pearson Education, Inc.

Mappiare, A. (1982). Psikologi Remaja, Surabaya: Usaha Nasional.

Rosenberg, M., Schooler, C., \& Schoenbach, C. (1989). Self-Esteem and Adolescent Problems: Modeling Reciprocal Effect, American Sociological Review, 54, 10041018.
Santrock, J.W. (2002). Life-Span Development, 13th Edition, University of Texas, Dallas: McGraw-Hill.

Staton, W.J. (1987). Fundamentals of Marketing, $8^{\text {th }}$ Edition, Singapore: McGraw Hill Book Company, Inc.

Steinberg, L. (2002). Adolescence, Sixth edition, New York: McGraw Hill, Inc.

Singla, R.K. (2008). Business Studies: Class XII, 2008-09, New Delhi: V.K. (India) Enterprises.

Sirgy, M.J. (1982). Self-Concept in Consumer Behaviour: A Critical Review, Journal of Consumer Research, 9(3), 287-300.

Taylor, S.E., Peplau, L.A., \& Sears, D.O. (2000). Social Psychology, 10th edition, USA: Prentice Hall.

Williams, B.K. \& Sawyer, S.C. (2011). Systems Analysis \& Design Methods (7th edition), New York: McGrawHill.

Yildirim, C. (2014). Exploring the Dimensions of Nomophobia: Developing and Validating a Questionnaire Using Mixed Methods Research, Graduate Theses and Dissertations, Lowa State University.

https://www.securenvoy.com/blog/2012/02/ 16/66-of-the-population-sufferfrom-nomophobia-the-fear-ofbeing-without-their-phone/ diunduh pada tanggal 24 Maret 2015. 
Psympathic, Jurnal Ilmiah Psikologi Desember 2017, Vol. 4, No. 2, Hal : 183 - 192 